\title{
The Empirical Analysis on Innovative of Philosophy Education Based on Unbiased Estimation
}

\author{
Xiao He \\ Department of Social Sciences,Xinxiang University,Xinxiang, China \\ hexiao_xxc@163.com
}

Keywords:empirical analysis; performance innovation; unbiased estimation

\begin{abstract}
The ideological and political education is the primary content of Chinese spiritual civilization construction, is one of the main ways to solve social contradiction and problem. The ideological and political education is very important and quite hard to do, especially in the condition of market economy, there are exist some relatively weak conditions in China 's ideological and political work, which cannot adapt to the development of modern society requirements. According to the current situation of ideological and political education of China, this paper draw lessons from the innovation of foreign ideological and political education teaching methods, further analyzed the inevitable trend of using foreign ideological and political innovation for reference. The empirical analysis on the important functional innovation of using foreign ideological and political teaching thought for reference open up new ways and research directions of China's development of ideological and political education.
\end{abstract}

\section{Introduction}

Ideological and political education is a social or community groups with certain ideas, politics, ethics, imposing on its members with purposed, planned and organized impact, making them form ideological and moral social practice activities that meet certain social requirements. Ideological work refers to put forward corresponding ideological guidance strategy on human consciousness and thinking, some political parties, organizations, class in order to protect their own interests and to ensure people to establish a correct understanding of society in the heart, its a kind of social activity which can correct deflected social development thoughts. The concept of political work is to make proper understanding and clear analysis on the current political situation, to adapt to the needs of the development of current political, is a kind of influence that the ruling party put on the present development thoughts, is a practical activity which a certain class, organization in order to protect their own interests, realize their own political agenda and political development[1]. With the development of our education, gradually appeared a lot of problems and obstacles in the process of teaching, we can also find some problems from the ideological and political education of our country, the designed teaching thought mode according to ideological and political work put forward by domestic schools are also inadequacy, which affect the domestic students build a healthy and complete values, morality, life view. Foreign Ideological and political education from the combination of theory and practice to find new ways of Ideological and political education, ideological and political education by shaping students' healthy personality and charisma, still lead to a new direction of thinking on political concept, bringing an opportunity for the state government to establish a correct Party ideological line.

\section{A summary of China's current ideological and political education}

A. The connotation and immanent connection of China's ideological and political education

The current China's political ideological and political work is the combination of ideological work and political work, and the ideological work and political work have both connection and differences. Ideological and political work itself exist intersection, the ideological content in ideological work have influence on political work[2]. From another point of view, the essence of ideological work is a kind of effective development, it can improve ideological weakness of young people. Specific are 
shown below.

As shown in Figure 1, China's political ideological work is the combination of political work and ideological work, the integrated thought work covers wide content, also involved connotation and essence of human thoughts and culture. Ideological work is divided into political and non-political, political ideological work itself refers to solve people's insufficient understanding of political and government development, solve people's insufficient world outlook, politics, legal system view[3]. Non-political ideological work is to solve the people's social life, management problems, production technical problems, living and production problems, mental health issues. Political work including propaganda, organization, cadres, security, united front work and discipline inspection work.

$B$. The practical application value of China's ideological and political education

The practical application value of China's ideological and political education including two aspects: first, from the ideological and political education itself, ideological and political education have the distinct characteristics of ideological aggregation, through different social class's interests, different national organizations make demands and modify their ideological and political education, it requires a Ideological and political education development line with strong political color; second, from the ideological and political education system and the function characteristics, its divided into ideological and non-ideological function. Specific are shown below [4].
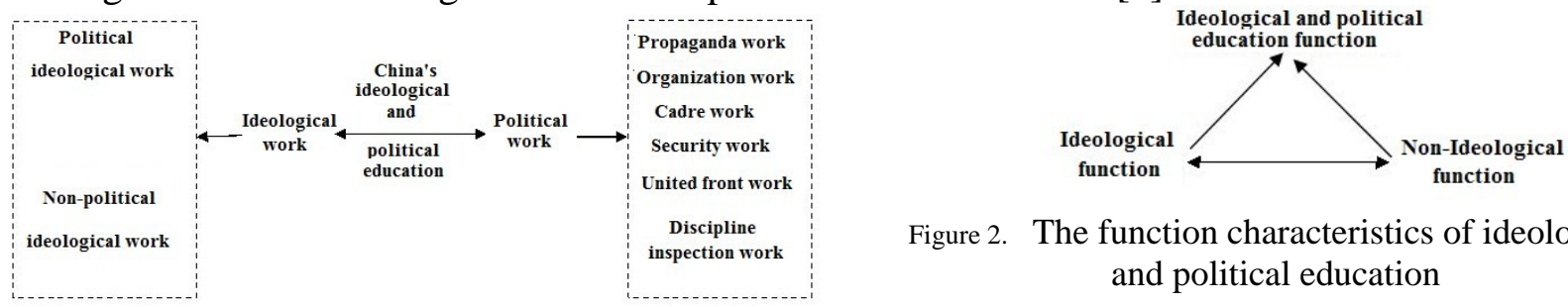

Figure 2. The function characteristics of ideological and political education

Figure 1. The connotation and immanent connection

of China's ideological and political education

As shown in Figure 2, the non-ideological function in ideological and political education refers to the non-class social characteristics and universal character of development, this kind of education can be develop and service for all people in society, is can maintain a sustainable development and existence of a regime, let political consciousness win support among the people, make people aware of the importance of ideology.

\section{The enlightenment of foreign ideological and political teaching thoughts on China's ideological and political education}

From an international range we can see that, no matter in the past during the cold war or under the background of modern globalization and diversification, countries have to maintaine and stand for their national interests. In the international community, ideological and political education is essential, is an important part of state policy. Ideological and political education itself is " software" construction, but in Singapore it through the system, policy, legal and other " hardware " to safeguard and ensure survival. Therefore, the government leadership of Singapore changed, but the ideological and political education can not be weakened, and vice versa, as a basic state policy unswervingly insist all the time.

Foreign Ideological and political education is the maintenance and communication channels to expresse national interest, in any country any period, if the government don't attach importance on ideological and political education, the juvenile crime rate is high, social is unrest, the country 's politics and economy target is difficult to reflect, and vice versa, the situation will be different. In the process of ideological and political education we need to do corresponding estimation on its effect and general parameters, we can find several unbiased estimation. In these unbiased estimation, which estimate result is better? To solve this problem, we need do further study to estimate the volume of effective features and requirements. Suppose $\hat{\theta}_{1}, \hat{\theta}_{2}, \ldots, \hat{\theta}_{k}$ are the unbiased estimation of $\theta$, if present[5]:

$$
\frac{\operatorname{Var}\left(\hat{\theta}_{i}\right)}{\operatorname{Var}\left(\hat{\theta}_{j}\right)}<1 \quad i \neq \mathrm{j} \quad i, j \in\{1,2, \cdots, k\}
$$


We call the estimation of $\hat{\theta}_{\mathrm{i}}$ is more effective than ${ }^{\hat{\theta}_{\mathrm{j}}}$ on $\theta$.

As shown in Figure 3, the estimated sampling distribution ratio curves A stands for is more more peaked than that curves $B$ stands for, so the corresponding estimate of $A$ is more effective than $B$ on parameter estimation of $\theta$ American Ideological and political education pay attention to the teaching of value concept, the core idea is to educate every students' patriotic feeling, let every student have hardship consciousness, make every students learning ideological and political the United States are living in a peace environment, so that they recognize themselves are in a superior environment, understanding the composition of survival mode, forming a more humane and moral ideas, establishing a sound personality charm, rich self values, social values, outlook on life, to establish a new education training direction and mode, and let the ideological and political education advance in a clear and fixed direction[6].

\section{The Inevitable trend analysis of using foreign ideological and political innovation for reference}

In our ideological and political teaching process, develop some skills and content of foreign ideological and political teaching become extremely necessary, the ideological and political teaching have profound significance in China's political development and ideological development, carry out ideological and political communication between various countries and regions also become very important, our country is able to learn the necessary ideological formation method and characteristic[7].we should learn its importance of foreign ideological and political education, according to its meaning and action to make our ideological and political education orientation. Mainly reflects in the following three aspects. Specific are shown in Table 1.

TABLE I. THE INEVITABLE TREND OF USING FOREIGN IDEOLOGICAL AND POLITICAL INNOVATION FOR REFERENCE

\begin{tabular}{|l|l|}
\hline \multirow{4}{*}{$\begin{array}{l}\text { The Inevitable trend of using } \\
\text { foreign ideological and political } \\
\text { innovation for reference }\end{array}$} & $\begin{array}{l}\text { First, the ideological and political education is an education practice widely exists in } \\
\text { human class society, which has a common goal and law. }\end{array}$ \\
\cline { 2 - 2 } & $\begin{array}{l}\text { Second, in the later stage of reform and opening up, the development of Ideological and } \\
\text { political education step into a new development stage, during which a lot of political } \\
\text { policy are put forward, Deng Xiaoping theory, three represents thought is the } \\
\text { development signal faceing modern social. }\end{array}$ \\
\cline { 2 - 2 } & $\begin{array}{l}\text { Third, strengthen the ideological and political education abroad is an inevitable trend } \\
\text { and the necessary pursue of the development of Marx spirit. }\end{array}$ \\
\hline
\end{tabular}

As shown in Table 1, the Inevitable trend of using foreign ideological and political innovation for reference mainly reflected in three aspects. In the discussion of foreign ideological and political innovation from the overall average inferences ${ }^{\mu}$, we always assume that the foreign ideological and political innovation from the overall variance $\sigma^{2}$ is known. [8]If $\sigma^{2}$ is unknown, we use the sample variance $\mathrm{s}^{2}$ instead of $\sigma^{2}$ participating in operation. Before the process of sampling, $\mathrm{s}^{2}$ is a reference random variable. In order to achieve the statistical inference of $\mathrm{s}^{2}$, must know the sampling distribution of $\mathrm{s}^{2}$, as the understanding of the sampling distribution $\overline{\mathrm{x}}$, so $\overline{\mathrm{x}}_{\text {can }}$ be used to infer $\mu$. If we do repeated sampling form the normal population of variance $\sigma^{2}$ with the same volume, the random variables of sample variance $\mathrm{S}^{2}$, after processing according to the formula $\frac{(n-1) S^{2}}{\sigma^{2}}$, are statistics of $\mathrm{X}^{2}$, obey the degrees of freedom for $(\mathrm{n}-1) \mathrm{X}^{2}$ distribution. That is:

$\mathrm{X}_{n-1}^{2}=\frac{(n-1) S^{2}}{\sigma^{2}} \mathrm{X}^{2}$ are non-negative variables, so the curve only appeared in the first quadrant. Specific are shown below.[9]

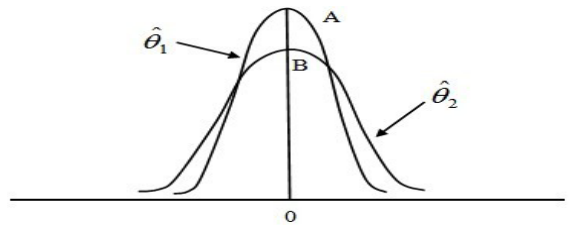

Figure 3. The enlightenment diagram of foreign ideological and political teaching thought on China's ideological and political education

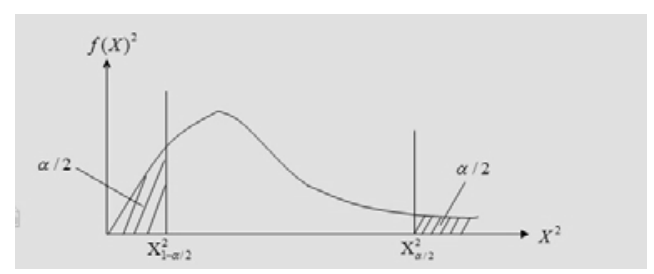

Figure 4. The variance diagram of the Inevitable trend of using foreign ideological and political innovation for reference

As shown in Figure 3, the distribution of $\mathrm{x}^{2}$ is a right skewed distribution, the distribution shape and location only depends on only the parameters -- degree of freedom $v(v=n-1)$. In most cases ${ }^{(v>3)}$, 
from the dot curve began to rise, reaching a peak at $\mathrm{v}-2$, then decreased gradually, reaching to the horizontal axis. With the increase of degree of freedom, slope slow down, gradually tend to normal distribution. When $\sigma^{2}$ and $n$ are certain, statistics $\frac{(n-1) S^{2}}{\sigma^{2}}=x^{2}$ in a certain probability under the protection of ${ }^{(1-\alpha)}$, always distributed in the interval $\mathrm{X}_{1-\alpha / 2}^{2}$ and $\mathrm{X}_{\alpha / 2}^{2}$ defined by $\mathrm{X}_{1-\alpha / 2}^{2}$ and $\mathrm{X}_{\alpha / 2}^{2}$. That is:[10]

$$
1-\alpha=\mathrm{P}\left(X_{1-\alpha / 2}^{2} \leq \frac{(n-1) S^{2}}{\sigma^{2}} \leq X_{\alpha / 2}^{2}\right)
$$

It can be concluded from the above formula :

$$
1-\alpha=\mathrm{P}\left(\frac{X_{1-\alpha / 2}^{2} \sigma^{2}}{n-1} \leq S^{2} \leq \frac{X_{\alpha / 2}^{2} \sigma^{2}}{n-1}\right) \text { is that, when } \sigma^{2} \text { is known, has a probability }{ }^{(1-\alpha)} \text { security } \mathrm{S}^{2} \text { falls in between }
$$
$\frac{\mathrm{X}_{1-\alpha / 2}^{2} \sigma^{2}}{\mathrm{n}-1}$ and $\frac{\mathrm{X}_{\sigma 2}^{2} \sigma^{2}}{n-1}$. from the foreign ideological and political innovation from the overall variance $\sigma^{2}$, we must accept the universality of ideological and political work, and do comparison analysis research on various countries' fundamental practice, in order to better understand the general law and trend of development of ideological and political work. In the future development of the ideological and political education, maintaining the basic ability of truly stable social situation and revitalize the ruling ability of government, enhance the power of social development, help the government to improve the trust level, change the formation of ideology.

\section{Conclusion}

Ideological and political education can be learned through the learning of advanced foreign diplomatic form of Ideological and political education, sent a delegation and visiting mission to make investigation and understanding about the foreign advanced social and political development ideology, learning the advanced ideology, understand the superiority content of thoughts, and improve the domestic shortage. Pay attention to the combination of family education and school education, forming a bidirectional teaching development, improve teaching effectiveness, improving the deficiencies and shortcomings, through the relationship between family, school, society, closer the formation of ideological in real life. Through the ideological and political education, enhance the students' support for the regime, to improve students' correct development thought consciousness, making students have a healthy body and mind quality, more in line with the needs of social development.

\section{References}

[1] Zhang Yaocan, Xu Zhiyuan. Analysis of ideological and political education and related important category[J].Journal of hebei party school authorities,2010(03):33-35

[2] Shi Shuchen. The subject review and investigation on ideological and political education[J]. Studies in Ideological Education,2010(02):101-105

[3] Hou Yong, SunQiang,Han Xingyu. Discipline and new understanding of the concept of ideological and political education[J]. Academic forum,2011(10):96-99

[4] Zhang Jianhui. Overview of our country's improvement and innovation according to foreign ideological and political education. The reform and innovation.2010(02):40-43

[5] YingJie,LiYuan. Analysis of the innovation sources of Ideological and political education method [J].China Education Innovation Herald,2011 (28):23-24

[6] Wang Xiaofei. Reference research of foreign Ideological and political education [D].Journal of Xi'an Jiaotong University,2011

[7] Zhang Yaocan. The modern ideological and political education science[M].Beijing: People's publishing house, 2010:132-135

[8] Shi Yunxia. The new changes and strategy research on the fields of ideology in our country [J].Ideological and political education, 2009(9):52-54

[9] Tang Li, Gao Yanjie. The characteristics and enlightenment of American schools' Ideological and political education[J]. Journal of Nanjing University of Science and Technology (social science edition ), 2009 ( 2):17-19

[10] Chen Lisi. The contemporary world's ideological and political education [M]. Beijing: China Renmin University Press, 2011:367-369 